\title{
THE HEALTH NEEDS OF THE BLACK ELDERLY POPULATION IN CERTAIN AREAS OF RURAL AND URBAN KWAZULU
}

\author{
M. Kumalo and L. R. Uys
}

\section{Problem Statement:}

Informal information received from Doctor M V Gumede, retired Secretary for Health - KwaZulu, now in his seventies, reveals that the $\mathrm{K}$ waZulu population is now aging because of better social care. $\mathrm{He}$ states that expectation of life is higher oday; during the days of King Shaka it was 41 years of age, during his father's days it was 60 years of age and during his day it is 68 years of age.

On the other hand, Shegog (1981)

advocates that most of the gains in survival were made in the half of the century before the advent of antibiotics and high technology medical care, and may be largely attributed to improvements in hygiene, nutrition and environmental conditions. In some developing countries life expectancy hardly reached beyond forty or fifty years of age.

The problem of old age in the black population is aggravated by the fact that there is a change in the structure of the black family. Today we have the nuclear family more mobile than it has ever been. The uprooting of an old person to a new and unfamiliar district away from established friends and neighbours, can lead to breakdown (Hawker 1974). Houses re smaller nowadays, children grow and need more space. The emotional strains and tension between the generations can be enormous. Although family ties are close, sharing a house is not generally an appropriate solution. Older people given choices would opt most frequently to maintain independence in their own local community. In this way, they retain status and maintain dignity as people in their own right.

In urban areas the extended family is breaking down. Childless older couples or single persons often find themselves without money or family to help (Dunham et al 1978). Adult children may lack the means to support their parents and, generally, no social security scheme exists or is funded adequately to provide a minimum income in old age.

There are usually few hospitals offering free medical services, and social services for the elderly are practically non existent. Older persons in rural areas are not necessarily much better off. As their younger relatives migrated to cities in search of an improved life, the old are increasingly left to fend for themselves.

\section{ABSTRACT}

The health needs of Black elderly in rural and urban KwaZulu was investigated through a survey. Interviews with 240 elderly was done, looking at the first and second level of the health facilities plan, as well as social support and health indicators. It was found that urban elderly are generally better off than rural elderly and a profile of need is described.

\section{OPSOMMING}

Die gesondheidsbehoeftes van Swart bejaardes in plattelandse en stedelike KwaZulu is ondersoek met 'n opname. Onderhoude is met 240 bejaardes gevoer en daar is gekyk na die eerste en tweede vlakke van die gesondheidsfasiliteit-plan, sowel as maatskaplike ondersteuning en gesondheidsindikatore. Daar is gevind dat die stedelike bejaardes oor die algemeen beter af is as plattelanders en in profiel van behoeftes is beskryf.

Many no longer have strength to sustain themselves in reasonable comfort.

The Zulu traditionally had the extended family providing for the welfare of individuals in need (Buthelezi Commission, 1982). Today, with the increasing incidence of the nuclear family rather than extended families and also a number of single parent families as well as the whole country in a state of deprivation and need, the family cannot meet most welfare needs.

The International Federation for the Aged, (1978) is convinced that there is a vital need in most countries for more effective planning for dealing with the problems of old age and promoting the wellbeing of older persons not only for the current generation of elderly, but for the many more who will soon fall within that category. And, it is vital for such planning to involve the aging themselves if it is to be effective (Dunham et al, 1978). Some developed countries have already undertaken planning efforts. Others are experimenting with the best means of carrying out this function. Many developing countries however are not yet aware of the growing problem in their midst and, consequently, have not begun planning for the aged. Governments' efforts are largely directed merely to keeping their fast growing population alive. Little energy or resources are directed to preparation for old age.

Against this background this study attempts to assess the health needs of the black elderly population in the rural and urban $\mathrm{K}$ waZulu region.

2. The Objectives Of The Study Are:

2.1 To assess health needs of the black elderly population in certain areas of the rural and urban KwaZulu region.

2.2 To identify the resources available for the aged; these resources include medical and nursing facilities, housing, transport and pension.

\section{Definition Of Terms}

For the purpose of this study:

Health needs includes primary health care needs (literacy, food, water, shelter, toilet) and access to appropriate health services (transport, clinic, finance).

Elderly is any person age 65 and over. Rural means areas under magisterial district.

Urban means a township.

4. Conceptual Framework For This Study Health needs are assessed according to the following categories derived from the literature.

\section{Primary health care}

Basic education

Nutrition

Water

Housing

Sanitation

\section{Recent history and lifestyle}

Accidents

Chronic diseases

\section{Social and heallh services}

Income

Transport

Health services

\section{Research Method}

A survey of Black elderly people was done. Data was collected through a structured interview and observations were done by three field-workers, all registered nurses. The interview schedule consists of 49 
questions covering all aspects contained in the conceptual framework.

Although the schedule was prepared for the computer to be used in analysis of the data, a very informal interview approach was used. The schedule can be completed in about 15 minutes.

The sample was a stratified, convenient sample, taken from certain rural and urban areas of $\mathrm{K}$ waZulu region. A sample of 240 was used.

Rural sample of 120 and a similar urban sample were taken from the following:

- Pension list $=60$. These respondents were contacted at pension pay points.

- Induna/Headman (rural), township manager (urban) $=20$. The headmen of Biyela, and the Zungu tribe were contacted, while the managers of Umlazi and $\mathrm{K}$ waMashu townships were approached.

- Clinics $=30$. Two clinics under Ngwelezana health ward in the Nseleni district, made up the rural sample and two clinics in the township in this area the urban group.

- Institution for care of aged $=10$. One institution $\mathrm{K}$ wabadala at Inkandla, residence were contacted (rural) and one in KwaMashu (urban).

A pilot study was done on a few urban and rural patients. The pilot study revealed that the elderly were not free to express themselves in the presence of the relatives or care givers, so during the major study the presence of other people was eliminated.

\section{Sample Description}

The sample of 240 elderly people were interviewed as planned. Of the 120 respondents from the urban area $53,8 \%$ were $65-74$ years old, $21,8 \%$ were $75-84$ years, $11,8 \%$ were $85+$ years and $12,6 \%$ were unsure of their ages. Of the 120 respondents from rural area $36,4 \%$ were 65-74 years old, $31,4 \%$ were $75-84$ years, $3,3 \%$ were $84+$ years and $28,9 \%$ were unsure of their ages.

The females in both areas outnumbered the males of the 120 - respondents from the urban area $17,6 \%$ were males and $82,4 \%$ were females. In the rural area $22,3 \%$ were males and $77,7 \%$ were females, which is not surprising as females outnumber males in the elderly population in most countries.

\section{Results}

\subsection{Primary health care indicators \\ Literacy}

It was found that the level of literacy is low among the black people. Of the 120 respondents from the urban area $13,4 \%$ could read English, 52,9\% could read Zulu, $3,4 \%$ could read other languages and $30,3 \%$ could not read anything. Of the 120 respondents from the rural area $8,3 \%$ could read English, $29,7 \%$ could read Zulu, none could read other languages, $62 \%$ could not read anything. The rural group had received primary school education and the medium of instruction was Zulu. The low literacy rate increases the problem reaching the elderly with any health teaching.

\section{Nutrition}

The following was taken as the daily requirements for a balanced diet for the elderly in a recent study about the standards of geriatric care:

2 litres of fluid

3 portions of dairy product

1 portion of citrus fruit, oranges, guavas and tomatoes

2 portions of whole wheat bread or equivalent

3 portions of vegetables of which one is dark green or yellow

1 serving of animal protein (over and above dairy products) (Uys and Hunt, 1990)

The diet of each respondent, was evaluated against these standards. The diet of 214 elderly lacked the requirement for a daily balanced diet and only 26 met with almost all the requirements. Most common deficiencies were in fluid intake, dairy products and citrus fruit, while whole wheat was the best.

Of the 240 respondents, 130 said they were not eating enough. They all ascribed it to lack of money, although some added secondary reasons such as decreased appetite.

Many of the respondents said that they bought food at local stores. They were allowed to make a food order on account once in between pension pay-days, but no more than that. This explains the 79 who said that the time between pensions was too long for the food to last. The food prices at the local shops were also high and as a result the elderly saved on food and did not buy sufficient food to last for two months, as the pension is paid every other month. Food also was finished before the next pension day due to a poor system of budgeting.

All respondents from the urban area used tap water, which is a safe supply. The respondents in the rural area used river water (46), which is unsafe for human consumption, as well as water from springs that were not protected (29). Borehole water provided safe water, but there were too few boreholes (2), resulting in the shortage of water supply. $4,2 \%$ of the respondents from the rural area said that they did not have enough water. It was found that sterilization of water from unsafe sources was not done either by boiling or use of sterilizing agents such as Jik, Javel or Milton.

Lack of adequate water contributed to poor hygiene conditions. The elderly in rural areas travelled distances to get water. It was discovered that $38,3 \%$ travelled less than $1 \mathrm{~km}, 25 \%$ (60 people) travelled 1 to $5 \mathrm{~km}$ and $2,1 \%$ (5 people) travelled more than $5 \mathrm{~km}$ to get water. Some depended on their adult children and grandchildren and good neighbours to get water for them, if not, they went to the extent of paying 50 cents for a 20 litre container of water.

\section{Housing}

The type of housing is described in Table 1. Older people who lived in the urban area were better housed in permanent structure except for a very small percentage of $1,7 \%$ who lived in shacks.

The highest percentage in the urban area lived in their own houses, that is the $55,5 \%$ of the 120 respondents. In the rural area the elderly who lived with their spouses made up $31,4 \%$ of the 120 respondents and 30.6 lived in sons and daughters house. A category which needs to be added is "foster home". For the purpose of this report such data was put into the category of the relatives as it is close to that description. Foster home is where other members of the community and neighbours become prominent as caregivers. Friends and neighbours play an important and special role as caregivers. When the elderly did not live with family, bereavement was the cause most commonly mentioned (29\%).

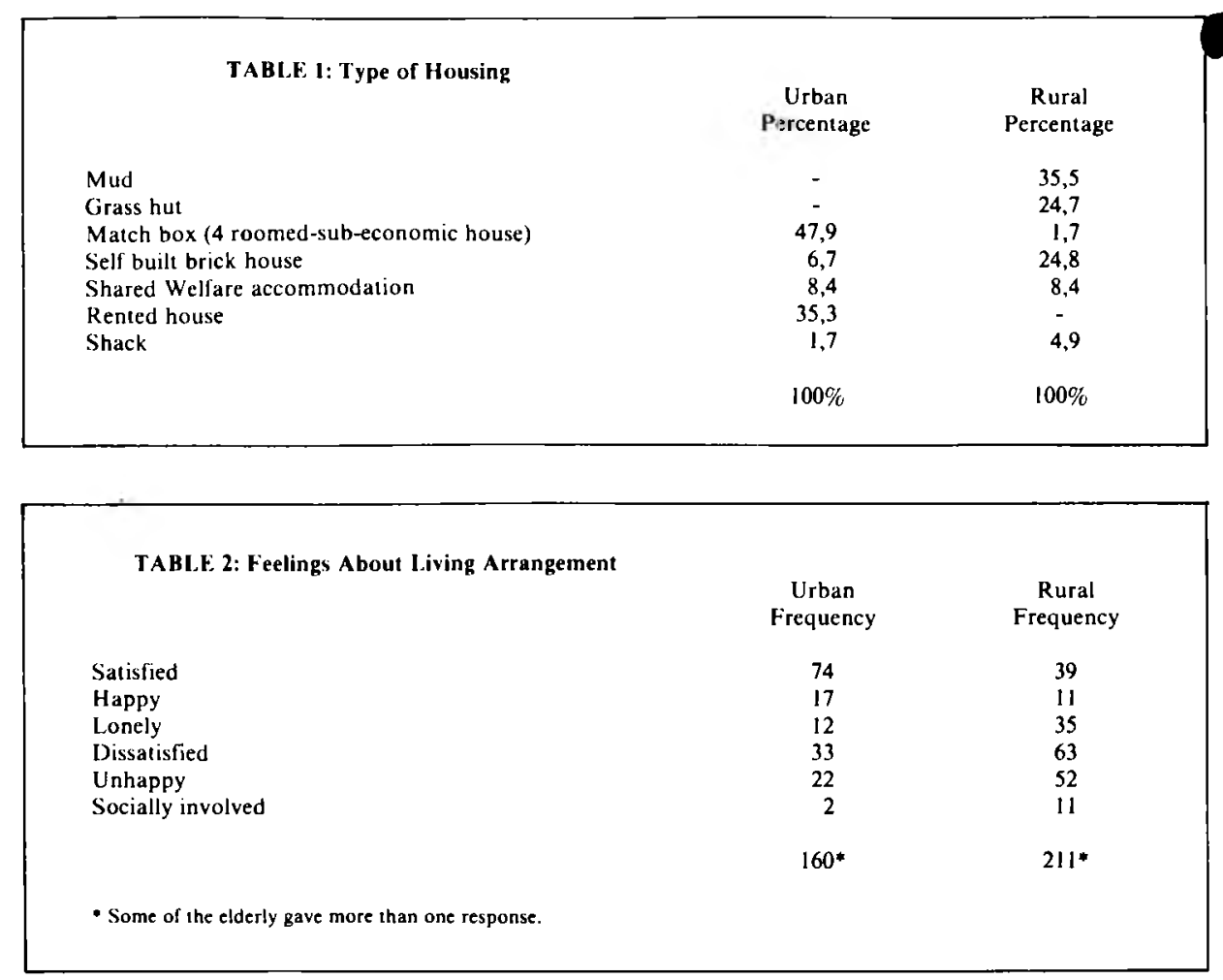


The feelings of the elderly about their living arrangement are summarized in Table 2. Negative feelings seem to be much higher in the rural group.

An incident related by one of the respondents in the urban residential facility illustrates the vulnerability of these people. One evening hooligans broke the window where two elderly females lived. The respondent heard them scream, but only ventured in the morning to check her neighbours. She then found that one was in a bad condition having been raped by a number of people. She looked for the other old lady and discovered her underneath the bed. She called her to come out, but did not get a response. She then pulled her out, only to find that she was long dead.

\section{Sanitation}

The respondents from the rural area stated that in spite of health education talks they did not believe in using pit privies because of cultural beliefs which restrict a bride

rom using the same seat as her father-in-

w. Not using a pit privy is a protective measure from witchcraft, the elderly stated. The witch cannot bewitch the whole family by the use of faeces from the pit privy, hence $40,5 \%$ used veld (exposed stool passed and left uncovered), a small figure of $1,2 \%$ used cat system (that is digging the hole and covering with soil).

Some of the respondents, resulting from health education talks given by field health workers, had changed their attitudes towards using pit privies. It was found that of the 120 respondents from the rural area $47,1 \%$ used pit privies. What interested the researcher was that some families built pit privies because of the pressure from "converted" Indunas (headmen). The head of the kraal would pay a fine if found without a pit privy, but no one ever used the pit privy.

\subsection{Recent history and lifestyle}

esponsibilities most common in the derly in both areas were housework, church work, looking after the garden, child caring, craft work and crochet work. A very low percentage also did washing for the aged, community involvement, sewing, voluntary work, nursing sick aged, poultry farming, casual worker.

The respondents that felt that their responsibilities were too much, mostly due to ill health were 16 from the urban area and 37 from the rural area. Those which felt that their responsibilities were not too much were 48 from the urban area and 28 from the rural area. Most of the elderly stated that their responsibilities were sometimes too much.

\section{Accidents and falls}

Thirty-four percent of the elderly in the urban area and $50 \%$ in the rural area had accidents in their later years. The highest percentage of accidents were due to falls, $26,1 \%$ from the urban area and $46,3 \%$ from the rural area.

\section{Chronic diseases}

Many older persons were in poor health.

TABLE 3: Chronic Diseases

$\begin{array}{rr}\text { Urban } & \text { Percentage } \\ & \text { Rural } \\ 3,4 & \\ 64,7 & 8,3 \\ 44,5 & 46,3 \\ 6,7 & 39,7 \\ 1,7 & 6,6 \\ 5,0 & 1.7 \\ .8 & 2,5 \\ & 1.7\end{array}$

They were especially subjected to such chronic diseases of the muscular, cardio vascular, and metabolic systems. Some experienced one or many chronic diseases (see Table 3 ). The elderly with muscular problems complained of backache, hip and knee joint pains.

\subsection{Social and health services}

\section{Income}

Old age pension was the most common source of income: $94,1 \%$ from the urban area and $96,7 \%$ from the rural area received government pension and a small percentage from the private sector. Two hundred and twenty-eight of the respondents stated that they had problems with their money supply and only 12 said that they are getting enough financial help. The problem of waiting too long (referring to the bi-monthly payment) was universal, while 144 said that they share their pension with family.

The results indicated that the largest percentage of the elderly collect their pension from the pay point. The elderly who had serious health limitations were helped by adult children, grandchildren or relatives with the collection of pension money. Of the 120 respondents from the urban area $63,9 \%$ spent nothing in collecting pension while $23,5 \%$ spent R5 and $2,5 \%$ spent R5-R 10 and $10,1 \%$ spent R 10. Over 20 respondents spent R10 in collecting pension, so a high percentage of pension to is used to pay for transport.

\section{Transport}

Many elderly had serious problems of transportation making it difficult to go shopping, visit clinics, friends and relatives, and generally keep active in the life of the community. The investigation was held during the time when Putco buses had been withdrawn from Umlazi due to riots, stoning and burning of buses. The only transport available were taxis and not enough to cover the transport requirements (see Table 4 ).

\section{Health services}

The availability of either mobile or residential clinics (as revealed in Table 5) is over $90 \%$, with traditional and spiritual healers as the second most common resources.

Of the 120 respondents from the urban area $68,9 \%$ used mobile or residential clinics and of the 120 respondents from the rural area $74,4 \%$ used mobile or residential clinics. The rest did not use clinics and gave different reasons, as reflected in Table 6.

The majority of the elderly reported that they did not pay for health services in the past, but recently they have been told to pay. Some used the hospital because it is the nearest health service. The hospital is

\begin{tabular}{|lrr|}
\hline & & \\
& TABLE 4: Transport Available & \\
& Urban & Percentage \\
& & Rural \\
Own car & 1,7 & 1,7 \\
Family car & 2,5 & 1,7 \\
Friends car & - & - \\
Regular bus & 10,1 & 79,9 \\
Taxi & 84,9 & 61,2 \\
Lifts & 5,9 & 3,3 \\
Ambulance &, 8 & 10,7 \\
\hline
\end{tabular}


TABLE 6: Reasons For Not Using Clinics

\begin{tabular}{lcc} 
& & Percentage \\
& Urban & Rural \\
Transport problems & &, 8 \\
Financial problems & 10,9 & 5,0 \\
Distance & - & 9,1 \\
Physical unable too tiring & 3,4 & 4,1 \\
Using traditional healer &, 8 & 6,6 \\
Bad experience with clinic &, 8 & 2,5 \\
& & \\
\hline
\end{tabular}

TABLE: 7: Observations Of Health Indicators

\begin{tabular}{|c|c|c|}
\hline & \multicolumn{2}{|c|}{ Percentage } \\
\hline & Urban & Rural \\
\hline \multicolumn{3}{|l|}{ Posture } \\
\hline Upright & 79.0 & 62,0 \\
\hline \multirow[t]{2}{*}{ Bent } & 21,0 & 38,0 \\
\hline & 100,0 & 100,0 \\
\hline \multicolumn{3}{|l|}{ Gait } \\
\hline Normal & 79,8 & 61,2 \\
\hline \multirow[t]{2}{*}{ Shuffling } & 20,2 & 38,8 \\
\hline & 100,0 & 100,0 \\
\hline \multicolumn{3}{|l|}{ Blood pressures } \\
\hline Diastolic below 95 & 48,7 & 61,2 \\
\hline \multirow[t]{2}{*}{ Diastolic above 95} & 51,3 & 38,8 \\
\hline & 100.0 & 100,0 \\
\hline \multicolumn{3}{|l|}{ Affect } \\
\hline Normal & 72,3 & 72,7 \\
\hline \multirow[t]{2}{*}{ Depressed } & 27,7 & 27,3 \\
\hline & 100,0 & 100,0 \\
\hline \multicolumn{3}{|l|}{ Vision } \\
\hline Clear & 42,9 & 30,6 \\
\hline \multirow[t]{2}{*}{ Myopic } & 57,1 & 69,4 \\
\hline & 100,0 & 100,0 \\
\hline \multicolumn{3}{|l|}{ Hearing } \\
\hline Clear & 89,9 & 68,6 \\
\hline \multirow[t]{2}{*}{ Hard } & 10,1 & 31,4 \\
\hline & 100.0 & 100,0 \\
\hline \multicolumn{3}{|l|}{ Nutritional state } \\
\hline Nourished & 67,2 & 44,6 \\
\hline Under nourished & 26,1 & 47,8 \\
\hline \multirow[t]{2}{*}{ Obese } & 6,7 & 7,6 \\
\hline & 100,0 & 100,0 \\
\hline \multicolumn{3}{|l|}{ Teeth } \\
\hline Normal & 21,0 & 18,2 \\
\hline Dentures & 10,9 & 6,6 \\
\hline No teeth & 9,2 & 10,7 \\
\hline \multirow[t]{2}{*}{ Dental caries } & 58,9 & 64,5 \\
\hline & 100,0 & 100,0 \\
\hline \multicolumn{3}{|l|}{ Mental acuity } \\
\hline Bright & 79,0 & 51,3 \\
\hline Confused & - & .8 \\
\hline \multirow{2}{*}{ Short-term-memory } & 21,0 & 47,9 \\
\hline & 100,0 & 100,0 \\
\hline
\end{tabular}

an expensive health service, which should be used only for referrals from clinics, for intensive medical and nursing care.

The pension money is calculated to cover the needs of the individual pensioner. The pension money was bound to be insufficient because it was used to cover the family expenses and even to the extent of educating the grandchildren.

\subsection{Health status}

Some of the respondents were very frail and needed care from their families and care givers. The high figures of dental caries in both urban and rural respondents (Table 7), indicate the need for health services within reach of the elderly for dental care and prevention of further dental problems. A shuffling gait was more common in the rural than in the urban area. This may result from under nourishment which was $47,8 \%$ in rural and $26,1 \%$ in the urban area. Diastolic blood pressure was higher in the urban area than in the rural area. The lifestyle and other problems encountered in the urban area, may be the reason for high diastolic pressure.

High rates of myopia was more common in the rural than in the urban areas. Of the 120 respondents from the rural area myopia was found in $69,4 \%$, and in the urban area it was $57,1 \%$. Myopic and dental caries figures, were high especially in rural areas, indicating that the elderly in the rural area have more health problems than in the urban area. The elderly in the rural area had less access to health services because of long distances, and lack of health services in the area.

\section{Conclusion and recommendations}

It is clear from the results that the situation of the rural elderly is generally poorer than that of their urban counterparts: their housing is poorer; and they are much more dissatisfied and unhappy with their living conditions; they feel they have too much responsibility; their distance from the clinics prevents more of them from using clinics and on observation they do worse in all health indicators. It is therefore understandable that this promotes urbanization, and can only be prevented by improving the health services and other support services in the rural areas.

A clear picture of the health practices (sanitation, water, diet) and health needs of this group of patients emerge, which should be used in the planning for this group and individual intervention by nurses. Some solutions from other countries (e.g. food stamps instead of financial assistance only) could be tried to address some of these problems. However, in many cases new and creative planning will be necessary.

\section{BIBLIOGRAPHY}

Aging International Information Bulletin on Aging

Vol. VIII No. I Al1B 1981 (a)

Vol. IX No. 3 A IIB 1982 (b)

Vol. XV No. 4 A 11 B 1988 (d)

Brearly C.P. 1975. Social work-ageing society. Boston, Routledge.

Buthelezi Commission Report 1982 Vol. I

Dunham A. et al. 1978. Toward Planning for the Aging in Local Communities, An International Perspective. Washington, International Federation on Aging.

Hawker M. 1974. Geriatrics for physiotherapis and the allied professions. London, Faber.

Shattoch F.D. 1981. Restraints and constraints to development. Liverpool, University of Liverpool.

Shegog R.F.A. 1981. The impending crises of old age. Oxford, Oxford University Press.

This article is based on research done for the degree M.Soc.Sc. in the Department of Nursing, University of Natal: Durban.

Magdalene Kumalo, M.Soc.Sc. (Nursing) University of Natal, Durban. Retired

Leana R. Uys, D.Soc.Sc.

University of the Orange Free State,

Professor, Department of Nursing. University of Natal, Durban. 